\title{
AgCuB nanoparticle eradicates intracellular S. aureus infection in bone cells: in vitro
}

\author{
Shahnaz Qadri ${ }^{1}$ - Tahir Abdulrehman ${ }^{2}$. Jamil Azzi ${ }^{3} \cdot$ Said Mansour $^{4} \cdot$ Yousef Haik $^{1}$ (I)
}

Received: 18 May 2019 / Accepted: 19 June 2019 / Published online: 24 July 2019

(C) The Author(s) 2019

\begin{abstract}
Staphylococcus aureus is the leading cause of internalized bone infection. Internalized bacteria are shielded from the immune system and antibiotics causing complications of conventional antibiotic treatment. In this study, we investigate silver-copperboron $(\mathrm{AgCuB})$ nanoparticles $(\mathrm{NPs})$ as a potential alternative to eradicate internalized bacterial infection without causing a harming effect on the host cells. The antimicrobial property, as well as the toxicity of the AgCuB NP's, is reported as dosedependent between 0 and $20 \mu \mathrm{g} / \mathrm{ml}$. Our results showed that $1-5 \mu \mathrm{g} / \mathrm{ml}$ of $\mathrm{AgCuB}$ NPs significantly reduced internalized infection in osteoblast cells with a single dose of treatment. The host cell toxicity observed at $20 \mu \mathrm{g} / \mathrm{ml}$ is ten times higher than the effective antimicrobial dose.
\end{abstract}

\section{Introduction}

Osteomyelitis by S. aureus is a damaging bone infection and if left untreated could cause patient death [1,2]. The bacterial infection is mostly a result of hematogenous spread from a skin infection, direct exposure to open wounds, and direct contamination during surgical procedures [3]. Prognosis of direct osteomyelitis is factored due to systemic factors such as obesity and diabetes. S. aureus is well known for its affinity to bind to the extracellular matrix (BEM) of osteoblast cells and direct interaction of the intracellular space following its internalization of the osteoblasts membrane [4]. Internalization of S. aureus leads to apoptosis of osteoblast cells [5]. S. aureus which colonizes inside the osteoblast cells is responsible for the spreading and relapse of infection in the presence of antibiotics [6]. Internalized S. aureus remains protected from the immune

Yousef Haik

yohaik@hbku.edu.qa

1 College of Science and Engineering, Hamad Bin Khalifa University, Doha, Qatar

2 College of Health and Life Sciences, Hamad Bin Khalifa University, Doha, Qatar

3 Brigham and Women's Hospital, Harvard Medical School, Boston, USA

4 Qatar Environment and Energy Research Institute, Hamad Bin Khalifa University, Doha, Qatar system as a result of the sheltered environment [7] leading to acute or chronic infection [8]. Recent studies have reported that the most commonly used antibiotic (vancomycin, daptomycin, and linezolid) failed to eradicate intracellular $S$. aureus infections [9]. Studies reported that S. aureus developed resistance to many types of antibiotics, e.g., all beta-lactams, linezolid, daptomycin, and vancomycin [10]. Hence, it is clear that therapy to eradicate intracellular infection is crucial for clinical management of osteomyelitis. Recently, several methods are employed to deliver antimicrobials at the intracellular environment [11]. For example, a planktonic $S$. aureus bacterium was used as a vesicle to deliver antibiotic-conjugated antibody at the intracellular environment [9]. Ultrasound-mediated delivery of antibiotic at the infection site was employed due to the enhancement of drug penetration in the cells due to the induced vibrations [12]. However, such techniques have not demonstrated effective intracellular delivery of antibiotics to eradicate intracellular infection significantly.

Metallic nanoparticles (NPs) and metal ions have shown a great promise of bactericidal activity in in vitro studies and wound infection therapy [13]. Among all metallic NPs, silver NP, copper NP, and silver-copper alloys have shown the most potent antimicrobial activity against a wide range of Grampositive or Gram-negative bacterial infections [14-16]. The silver-copper alloy NPs have been reported as the most effective antimicrobial by the release of dual ions $(\mathrm{Ag}+, \mathrm{Cu}+) \mathrm{com}$ pared with silver alone or copper alone nanoparticles; this ion release process is believed to cause DNA damage of the bacteria $[17,18]$. Silver-copper-boron $(\mathrm{AgCuB})$ have been 
studied as antimicrobial therapy in osteomyelitis animal model [19]. Exospore of $\mathrm{AgCuB}$ nanoparticles related immune response and its role in inflammation has been reported which depicted that an overdose can cause hepatotoxicity [20]. The in vitro study of $\mathrm{AgCuB}$ NP's toxicity in osteoblast cells and efficiency of antimicrobial activity at the intracellular level has not been reported.

This study reports $\mathrm{AgCuB}$ NP's ability to eradicate the intracellular infection of $S$. aureus invaded into osteoblast cells and $\mathrm{AgCuB}$ NP's toxicity to the osteoblast cells. We have added boron element with $\mathrm{Ag}-\mathrm{Cu}$ because boron is a known anticorrosive agent that delays the oxidation of copper [21, 22]. Copper oxide has less antimicrobial activity than $\mathrm{Cu}^{0}$, $\mathrm{Cu}^{+}$; hence, it is essential to minimize copper oxidation for retaining sufficient antimicrobial property of copper nanoparticles or silver-copper nanoparticles. A massive work of antimicrobial property for silver or copper nanoparticles appears in the open literature; however, the antimicrobial activity of $\mathrm{AgCuB}$ NPs in osteoblast cells has not been studied. We believe this is the first report that addresses the effectiveness of $\mathrm{AgCuB}$ nanoparticle as an antimicrobial agent for eradicating the internalized bacterial infection in osteoblasts and this study identifies a therapeutic tolerance dose of $\mathrm{AgCuB}$ NPs.

\section{Methods and materials}

\subsection{Synthesis of nanoparticles}

$\mathrm{AgCuB}$ NPs were synthesized and characterized as discussed in [20]. Briefly, 0.1 M salt of silver nitrate, copper sulfate, and boric acid in a ratio of 70:20:10 respectively was mixed in ethylene glycol and after vigorous stirring, $10 \mathrm{mM}$ each of L-cysteine and sodium hydroxide was added in a final volume of $20 \mathrm{ml}$ which was added dropwise to the round bottom flask containing $10 \mathrm{mM}$ of hydrazine hydrate and $10 \mathrm{mM}$ of sodium citrate. Followed by vigorous mixing at 2000 rpm using magnetic stirrer bar, the reaction was continued under argon atmosphere for $6 \mathrm{~h}$, until a dark brown color is formed. Nanoparticles were precipitated using acetone then washed with ethanol, and nanoparticle pellet was resuspended in water and collected by centrifugation at $10,000 \mathrm{~g}$. The centrifugation process was repeated at least 5 times to remove the traces of salts and hydrazine hydrate. A final pellet of nanoparticles obtained was flash frozen with liquid nitrogen and dried powdered using a freeze dryer. Nanoparticles in powder form were desiccated and stored in dark screw-capped bottles at $-80{ }^{\circ} \mathrm{C}$ for future use.

\subsection{Nanoparticle preparation for characterization}

Synthesized $\mathrm{AgCuB}$ NPs were diluted in ethanol and quickly sonicated. After sonication, $5 \mu \mathrm{l}$ of nanoparticles was added to transmission electron microscope (TEM) holey carbon-coated copper grids and was kept under desiccation. The TEM (TalosF200X) was used to analyze the size and shape of nanoparticles. The energy-dispersive X-ray (EDX) detector installed on TalosF200X was used to identify the distribution of elements in nanoparticles at high magnification. The hydrodynamic size and zeta potential were measured after dispersing nanoparticles in deionized water, and $1 \mathrm{ml}$ of nanoparticles using 5-ml syringe was loaded in the disposable zeta potential cuvette (DTS1070, Malvern). This cuvette was used for measuring zeta potential and size in the Zetasizer (ZSP-Malvern). The percentage of silver, copper, and boron was confirmed by inductive coupled optical emission spectroscopy (ICP-OES) that was used to characterize the elemental analysis. Briefly, $10 \mathrm{mg} / \mathrm{ml}$ of $\mathrm{AgCuB}$ nanoparticles was digested in $5 \%$ nitric acid in a volumetric flask covered with aluminum foil and was kept for $2 \mathrm{~h}$ at room temperature. Standard addition method was used to identify the concentration of silver, copper, and boron elements. The final working concentration of digested nanoparticles was made to $10 \mathrm{ppm}$. The standard curve was generated by using a multielement standard solution containing silver, copper, and boron, and nanoparticle-digested solution was spiked with 1,5 , and $10 \mathrm{ppm}$ of standard solutions before the machine was calibrated for silver, copper, and boron elements with a minimum detection limit of $50 \mathrm{ppm}$.

\subsection{Bacterial strain and growth}

The S. aureus strain was obtained from ATCC (Cat\# 700260) form a clinical isolate of human osteomyelitic bone. The stock culture was streaked on T-soy agar plates and was stored in glycerol at $-80^{\circ} \mathrm{C}$. Bacterial colonies, grown on T-soy agar plates, were inoculated into a $5 \mathrm{ml}$ of T-soy broth and cultured stationary overnight at $37^{\circ} \mathrm{C}$ with aeration. The overnightgrown bacterial suspension was then sub-cultured at 1:5 ratio and grown to mid-log phase for another $2 \mathrm{~h}$ with shaking at $200 \mathrm{rpm}$ and was stopped when O.D. reached to 0.5 measured at $600 \mathrm{~nm}$ wavelength to confirm the CFU's $/ \mathrm{ml}$ at mid-log growth phase, which was approximately $5 \times 10^{7} \mathrm{CFU} / \mathrm{ml}$. Cells were harvested by centrifugation for $20 \mathrm{~min}$ at $4300 \mathrm{~g}$ and pellet was washed with PBS. Serial dilutions were prepared in sterile PBS for antimicrobial assay in DMEM with $10 \%$ fetal calf serum cell culture or osteoblast cells invasion assay. Prior to antimicrobial test, a growth curve of $S$. aureus in DMEM:F12 cell culture media was plotted by inoculating $1 \times 10^{6} \mathrm{~S}$. aureus in $1 \mathrm{ml}$ of DMEM cell culture media with $10 \%$ fetal calf serum and $2 \mathrm{mM}$ L-glutamine was added to $1.5 \mathrm{ml}$ of Eppendorf tubes and was kept in $37^{\circ} \mathrm{C}$ dry incubator with shaking at $220 \mathrm{rpm}$, every $30 \mathrm{~min}$ of incubation absorbance was measured at $600 \mathrm{~nm}$ wavelength. A sigmoidal growth curve was determined which explains the feasibility of growing $S$. aureus in DMEM cell culture media. S. aureus 
co-culture with host cells and its growth in animal cell culture media has been studied earlier [23, 24].

\subsection{AgCuB nanoparticle antimicrobial assay}

The antimicrobial assay was carried out in 1.5-ml Eppendorf tubes with $5 \times 10^{5} \mathrm{CFUs} / \mathrm{ml}$ of Gram-positive $S$. aureus in $1 \mathrm{ml}$ of phenol-free Dulbecco's modified Eagle's medium (DMEM)/Hams's F12 medium (DMEM/F12; Sigma USA); media were supplemented with $10 \%$ fetal bovine serum (FBS) and L-glutamine $2 \mathrm{mM}$. The antimicrobial assay was done in triplicate similar to the macro-dilution method of the antimicrobial assay [25]. The antimicrobial test was performed by adding a varied concentration of $\mathrm{AgCuB}$ nanoparticles ranging between 1 and $5 \mu \mathrm{g} / \mathrm{ml}$. The lids of each Eppendorf tube were closed and placed in a dry incubator with shaking at $220 \mathrm{rpm}$ at $37^{\circ} \mathrm{C}$ temperature. The incubation was carried for 1, 2, 3, 4, 5, or $6 \mathrm{~h}$. Post-incubation, S. aureus were harvested by centrifugation at $4000 \mathrm{~g}$ and pellet was resuspended in PBS buffer; serial dilutions were made and $100-\mu \mathrm{L}$ aliquots was plated on T-soy agar plates. CFUs were enumerated after overnight incubation.

\subsection{Human osteoblast invasion assay and intracellular antimicrobial assay}

The hFOB 1.19 human osteoblast cell line was obtained from ATCC (Cat\# CRL-11372). Cells were cultured as per ATCC recommendations in $10 \%$ FBS phenol-free $\mathrm{DMEM} / \mathrm{F} 12$ and G418 $-300 \mu \mathrm{g} / \mathrm{ml}$. The invasion assay of osteoblast cells was followed as reported by Ning et al. [26] Osteoblast cells were seeded in a density of $0.3 \times 10^{6}$, cultured overnight in each well of a 6 -well sterile tissue culture plate. Following incubation, cells were washed six times with antibiotic-free media, then infected with $S$. aureus at a ratio of 250:1 $(\mathrm{MOI}=250: 1)$ for $2 \mathrm{~h}$. Cells were then washed three times with antibiotic free media and incubated in medium containing $200 \mu \mathrm{g} / \mathrm{ml}$ of gentamicin for $2 \mathrm{~h}$ to eradicate non-internalized bacteria. After another cycle of three washes, nanoparticles were added at a final concentration of $2 \mu \mathrm{g} / \mathrm{ml}$ to the osteoblast cell cultures in antibiotic-free media and incubated for further 24 or $48 \mathrm{~h}$. Controls were grown under similar conditions except NPs were not added to the culture. After incubation, cells were then washed again three times and harvested after trypsinization in $1 \mathrm{ml}$ of $0.25 \%$ of trypsin (Sigma Cat \# T 4049). Cell lysates were prepared in $0.5 \mathrm{ml}$ of lysis buffer (PBS $+0.1 \%$ Triton $\mathrm{X}-100)$ and serially diluted in $1 \mathrm{ml}$ of PBS buffer. A total of $100 \mu \mathrm{L}$ from each dilution was plated on T-soy agar plate and incubated overnight for enumeration of intracellular bacterial CFUs.

\subsection{Confocal microscopy to visualize dead and live bacteria}

Osteoblast cells were cultured on 18-mm coverslips in a 6well culture plate and were co-cultured with $S$. aureus in a similar method as discussed above for bacterial invasion assay. $S$. aureus-infected osteoblast cells were treated with or without $2 \mu \mathrm{g} / \mathrm{ml}$ of nanoparticles and were incubated for 24 or $48 \mathrm{~h}$. Following incubation, each well was washed six times with pre-warmed PBS buffer to wash out extracellular bacteria. After washing, coverslips with growing osteoblast cells were treated with $0.05 \%$ of saponin (Sigma Cat \# 47036) in pre-warmed PBS buffer and were incubated for $15 \mathrm{~min}$ at $37{ }^{\circ} \mathrm{C}$ in a $\mathrm{CO}_{2}$ incubator. Cells were washed again to remove saponin with pre-warmed PBS buffer, a fluorescent stain from Invitrogen (Cat \# L-7012) with two components of Dye SYTO 9, $3.34 \mathrm{mM}$ (Component A) $300-\mu \mathrm{L}$ solution in DMSO, and propidium iodide, $20 \mathrm{mM}$ (Component $\mathrm{B}$ ) $300-\mu \mathrm{L}$ solution in DMSO. Both of the dye components were mixed 1:1 ratio as directed by the supplier. Six-well culture plates were fed with fresh $2 \mathrm{ml}$ of PBS buffer $\mathrm{pH} 7.4$ at $37^{\circ} \mathrm{C}$ and then $3 \mu \mathrm{L}$ of the mixture of component $\mathrm{A}$ and $\mathrm{B}$ of dye was added to each well. Plates were incubated in the dark for $10 \mathrm{~min}$. After incubation, coverslips were washed three times with warm PBS buffer pH 7.34 to remove the unbound stain. Coverslips with growing cultured cells were removed gently with the help of pointed forceps and were placed on a glass slide containing $50 \mu \mathrm{L}$ of $10 \%$ glycerol with cells lying between coverslip and the glass slide. Slides were then examined under a confocal microscope. The excitation/emission maxima for SYTO 9 stain is $480 / 500 \mathrm{~nm}$ and for propidium iodide $535 / 617 \mathrm{~nm}$. Slides were examined with Carl Zeiss Axio Observer Z confocal Microscope. Confocal scanning was done along $X Y Z$ plane, $z$ height was fixed at $15 \mu \mathrm{m}$ and each section was scanned at 500-nm distance.

\subsection{WST1 survival assay}

Wst1 kit was purchased from Clontech (Cat \# 630118). Standard protocol was followed as directed by the manufacturer in a 96-well plate with 10,000 osteoblast cells/well and nanoparticles with concentrations 1, 5, 10, 15, 20, and $30 \mu \mathrm{g} / \mathrm{ml}$ were added in different wells and incubated for $24 \mathrm{~h}$. After incubation, nanoparticles were washed and fresh medium was fed. Wst1 assay was performed as directed by the manufacturer. Briefly, after $24 \mathrm{~h}$ of incubation of nanoparticles with osteoblast cells in a 96-well plate, cells were fed with $100 \mu \mathrm{L}$ of fresh media and incubated for $2 \mathrm{~h}$. Followed by adding $10 \mu \mathrm{L}$ of Wstl reagent in each well, it was mixed gently for $1 \mathrm{~min}$ on an orbital shaker and plate was kept at $37{ }^{\circ} \mathrm{C}$ in a $\mathrm{CO}_{2}$ incubator for $2 \mathrm{~h}$. After incubation, the plate was removed and gently mixed on an orbital shaker to ensure homogenous distribution of color. Absorbance was measured

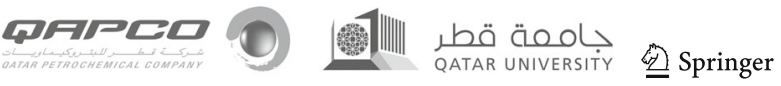


at a wavelength of $450 \mathrm{~nm}$ using Bio-tek UV-Vis absorbance Plate Reader.

\subsection{Oxidative stress measurement assays}

Osteoblast cells were grown in a T-25 flask as discussed above. Different concentrations of nanoparticles $1,5,10$, or $15 \mu \mathrm{g} / \mathrm{ml}$ were added and incubated for $24 \mathrm{~h}$. Following nanoparticle incubation, cells were washed with PBS buffer $\mathrm{pH} 7.4$ and were lysed in a cold lysis buffer pH 8.8 (50 mM of Tris and $1 \mathrm{mM}$ of EDTA) with protease inhibitor (Sigma Cat. \# P8340). Cell disruptor was used for quick cell lysis. The cell lysate was collected in Eppendorf tube and centrifuged at $10,000 \mathrm{~g}$ for $10 \mathrm{~min}$ in cold centrifuge and supernatant was collected for glutathione assay, catalase activity, and carbonyl content. Total protein content in the supernatant was measured by BCA assay (Thermo Scientific Cat. \# 23227) and was used as directed by the manufacturer. Briefly, reagents $\mathrm{A}$ and $\mathrm{B}$ were mixed in $50: 1$ ratio and $180 \mu \mathrm{L}$ of the mixture of $\mathrm{A}$ and B was added to $20 \mu \mathrm{L}$ of sample or dilutions of the standard curve. Plate was covered and incubated for $30 \mathrm{~min}$. Absorbance was measured at $562 \mathrm{~nm}$ by UV-Vis Bio-tek absorbance Plate Reader.

\subsection{Glutathione assay}

Reduced glutathione was measured by a biochemical assay as in [27] from the cytosolic fraction of cell extract. Reduced glutathione (GSH, Sigma Cat. \# G6013) or 5,5dithio-bis-(2-nitrobenzoic acid) (DTNB) was prepared in Tris EDTA buffer with $2.5 \mathrm{mM}$ each. Standard curves were plotted by taking $100 \mu \mathrm{L}$ of $2.5 \mathrm{mM}$ GSH in a 96well plate and serially diluted, followed by adding $100 \mu \mathrm{L}$ of $2.5 \mathrm{mM}$ DTNB reagent in each well. The plate was incubated at dark for $5 \mathrm{~min}$ and absorbance was measured at $405 \mathrm{~nm}$ and a standard curve was plotted. Similarly, $100 \mu \mathrm{L}$ of the cytosolic fraction of treated or non-treated cells was added to a 96-well plate and followed by adding $100 \mu \mathrm{L}$ of $2.5 \mathrm{mM}$ DTNB reagent. The plate was incubated in the dark for $5 \mathrm{~min}$ and absorbance was measured at $405 \mathrm{~nm}$ and concentration of reduced glutathione was calculated from the standard curve and was plotted as nmoles/ $\mathrm{mg}$ of total protein.

\subsection{Protein carbonyl and catalase assay}

Protein carbonyl content and catalase activity were measured by using their respective kits obtained from the Cayman Cat \# Nos 10005020 and 707002 respectively. Both kits were used as directed in manufacturer's protocol.

\subsection{Super oxide dismutase assay}

The assay was performed as described by the manufacturer (Cayman Cat \# 706002). Briefly, osteoblast cells were cultured in a T-25 flask up to $70 \%$ confluency, fresh media were fed to the cells and treated with different concentrations of nanoparticles ranging from 1 to $20 \mu \mathrm{g} / \mathrm{ml}$ and were incubated for 24 or $48 \mathrm{~h}$. Post-incubation cells were harvested by gently scrapping using rubber policeman and cells were homogenized in a recommended buffer (20 mM HEPES buffer, $\mathrm{pH}$ 7.2, containing $1 \mathrm{mM}$ EGTA, $210 \mathrm{mM}$ mannitol, and $70 \mathrm{mM}$ sucrose) supplied by the manufacturer as mentioned in the assay kit. A standard curve was generated and cellular super oxide dismutase (SOD) was calculated by following the instructions of the manual kit.

\subsection{Ratio-fluorescence assay of C11-BODIPY 581/591}

Osteoblast cells were plated on costar flat bottom 96-well plate at a density of 15,000 cells/well and were cultured until $80 \%$ confluent. Cells were treated with different concentrations of nanoparticles of $1,5,10,15$, or $20 \mu \mathrm{g} / \mathrm{ml}$. The negative control group was non-treated and two other groups were left non-treated for inducing oxidation which is taken as positive controls. Cells were incubated for $24 \mathrm{~h}$ in a carbon dioxide incubator at $37^{\circ} \mathrm{C}$. Post $24 \mathrm{~h}$ of incubation time, cells were rinsed with pre-warmed PBS and were fed with fresh media with or without nanoparticles. Negative controls were fed with fresh growth media without nanoparticles while as positive control wells received $5 \mathrm{mM}$ or $10 \mathrm{mM}$ of hydrogen peroxide in pre-warmed PBS buffer. To each well (controls + samples), $5 \mu \mathrm{M}$ of C11-BODIPY 581/591 was incubated for $30 \mathrm{~min}$ in a $\mathrm{CO}_{2}$ incubator at $37{ }^{\circ} \mathrm{C}$. Fluorescence was measured at both the wavelengths at the following excitation and emission wavelengths 575/595 and 505/515 for red and green respectively using Synergy-2 Bio-tek Fluorometer. Red fluorescence emission data was normalized to $100 \%$ from the negative control group, while green fluorescence emission data was normalized to $100 \%$ with $10 \mathrm{mM}$ hydrogen peroxide from the positive control group. All treated groups were normalized with positive and negative controls.

\subsection{LDH assay}

CytoTox-ONE assay kit was purchased from Promega Cat \# G7890 to measure the lactate dehydrogenase (LDH). The protocol was followed as directed by the manufacturer. Briefly, osteoblast cells were seeded in a 96-well plate with cell density of 15,000 cells/well. Growing cells were treated with a varied concentration of nanoparticles from 1 to $20 \mu \mathrm{g} / \mathrm{ml}$ or without nanoparticles in a final volume of $100 \mu \mathrm{L}$ of phenolfree media and plate was incubated for $24 \mathrm{~h}$ in a $\mathrm{CO}_{2}$ incubator at $37{ }^{\circ} \mathrm{C}$. After incubation time, 96-well plate and reagent 
assay kit were equilibrated at $22{ }^{\circ} \mathrm{C}$ (room temperature) for 20-30 min. After equilibration, each well was added $100 \mu \mathrm{L}$ of CytoToxic-ONE reagent. Positive control wells were added with $2 \mu \mathrm{L}$ of lysis buffer for maximum LDH release (lysis buffer provided with assay kit).After, cell culture plate was incubated for $20 \mathrm{~min}$ at $22{ }^{\circ} \mathrm{C}$ (room temperature). Following incubation, $50 \mu \mathrm{L}$ of stop solution was added to each well. The plate was shaken for $10 \mathrm{~s}$; Fluorescence was measured at 560/590 Ex/Em by using synergy-2 Bio-Tek fluorometer. All fluorescence values obtained were subtracted with the fluorescence values of the blank culture medium. Percent of toxicity was calculated as:

$=100 \times \frac{\left(\mathrm{LDH}_{\text {lysed }}-\mathrm{LDH}_{\text {exposed }}\right)}{\left(\mathrm{LDH}_{\text {lysed }}-\mathrm{LDH}_{\text {control }}\right) .}$

where $\mathrm{LDH}_{\text {lysed }}$ is the $\mathrm{LDH}$ released by lysing solution; $\mathrm{LDH}_{\text {exposed }}$ is the LDH released by exposing nanoparticles; $\mathrm{LDH}_{\text {control }}$ is the LDH released from the non-treated group.

\section{Results and discussion}

\subsection{Nanoparticle characterization}

Silver-copper-boron nanoparticles' shape and size were obtained by transmission electron microscope (TEM) at $200 \mathrm{kV}$; the average size of the particles was $20 \pm 3 \mathrm{~nm}$ (Fig. 1A). The hydrodynamic diameter obtained by a Zetaszier showed the average size of the nanoparticles to be $58 \mathrm{~nm}$ (Fig. 1C). This larger size compared with size obtained by TEM is attributed to the agglomeration of nanoparticles. The zeta-potential of nanoparticles was greater than $-50 \mathrm{mV}$ (Fig. 1B), which depicts that the nanoparticles were fairly stable besides their larger hydrodynamic size. The distribution of silver and copper elements within the nanoparticles was further confirmed by energy-dispersive X-ray (EDX) installed to the TEM. The EDX elemental mapping showed a homogenous distribution of $\mathrm{Ag}$ and $\mathrm{Cu}$ elements within the nanoparticles. Fig. 1D-F show the high-resolution dark field image of the NPs and the distribution of $\mathrm{Ag}$ and $\mathrm{Cu}$ elements within the NPs. The EDX spectrum is shown in Fig. 1G. The presence of silver and copper elements within nanoparticle was characterized by EDX elemental mapping which showed the homogenous distribution of $\mathrm{Ag}$ and $\mathrm{Cu}$ elements within the nanoparticles; hence, these nanoparticles of $\mathrm{Ag}-\mathrm{Cu}-\mathrm{B}$ could be an alloy form. The boron has a lower atomic number, as a result, it cannot be detected by EDX spectroscopy; however, B was detected by inductively coupled plasma optical emission spectroscopy (ICPOES)(Fig. 1H) [20].

\subsection{AgCuB nanoparticle antimicrobial study}

Antimicrobial properties of $\mathrm{AgCu}$ nanoparticles in vitro have been reported before [28]; however, the antimicrobial property of $\mathrm{AgCu}$ or $\mathrm{AgCuB}$ nanoparticles on internalized infection in osteoblast cells has not yet been reported. We recently showed that the antimicrobial effect $\mathrm{AgCuB}$ NPs effectively eradicating the bone infection in an osteomyelitis mouse model [19]. In this study, the antimicrobial property of $\mathrm{AgCuB}$ nanoparticles is evaluated against $S$. aureus-invaded mammalian osteoblast cells.

It was found that DMEM:F12 media with growth supplements is feasible for culturing $S$. aureus as shown in Fig. 2A; however, the growth was slower than TSB broth. The $S$. aureus was harvested from TSB broth that was used in the antimicrobial assay; hence, OD values in growth curve obtained were confirmed by plating serial dilutions on the agar plate, and colony-forming units were enumerated and bacterial dilutions were prepared using these OD values in antimicrobial assays as shown in Fig. 2C. The antimicrobial property of the $\mathrm{AgCuB}$ NPs was evaluated as a function of the dose and incubation time. Fig. 2B shows that doses of 4 or $5 \mu \mathrm{g} / \mathrm{ml}$ eradicate all 5.5 logs of CFUs in $4 \mathrm{~h}$, while as $2 \mu \mathrm{g} / \mathrm{ml}$ reduced the CFU's count by $2.2 \operatorname{logs}$ in $6 \mathrm{~h}$ which was more than $99 \%$, In this study, we reported that $\mathrm{AgCuB} \mathrm{NP}$ has minimum inhibitory concentration $\left(\mathrm{MIC}_{90}\right.$ ) of $2 \mu \mathrm{g} / \mathrm{ml}$, and it has been reported earlier that $\mathrm{AgCu}$ nanoparticles have $\mathrm{MIC}$ of $2 \leq \mu \mathrm{g} / \mathrm{ml}$ [18]. Several studies reported the MIC for Ag or $\mathrm{AgCu}$ nanoparticles which vary from 10 to $100 \mu \mathrm{g} / \mathrm{ml}[28$, 29]. The antimicrobial property of a nanoparticle depends on the size, shape, composition, and the efficiency of ions released in the medium. The surface coating of NPs with polymeric material can interfere the ability of ion release in aqueous medium; hence, the nanoparticles have to be used as naked or organic ligands grafted on the surface. Oxidation of $\mathrm{Cu}$ in a $\mathrm{AgCu}$ complex reduces antimicrobial property of NPs [30]. The surface modification of $\mathrm{AgCu}$ antimicrobial NPs with a suitable coating or by adding with an anticorrosive agent has not been yet reported. In here, we reported the employment $\mathrm{AgCuB}$ nanoparticles are effective to prolong the antimicrobial effect up to $48 \mathrm{~h}$ in internalized infection.

\subsection{Eradication of internalized S. aureus}

$S$. aureus was incubated with osteoblasts. The $S$. aureus-invaded osteoblasts are at 250:1. The multiplicity of infection (MOI) was significant to develop infection within the osteoblasts. In a $24 \mathrm{~h}$ of incubation with NPs, we observed 1.1 or $2.1 \mathrm{log}$ reduction of CFU's when the NP concentration was at 2 or $5 \mu \mathrm{g} / \mathrm{ml}$, respectively, while in a $48 \mathrm{~h}$ of incubation, we observed a 2.1 or $4.0 \log$ reduction for 2 or $5 \mu \mathrm{g} / \mathrm{ml}$ of $\mathrm{AgCuB}$ NPs, respectively. Our results showed a significant antimicrobial effect when incubated for $48 \mathrm{~h}$. This could be attributed to 

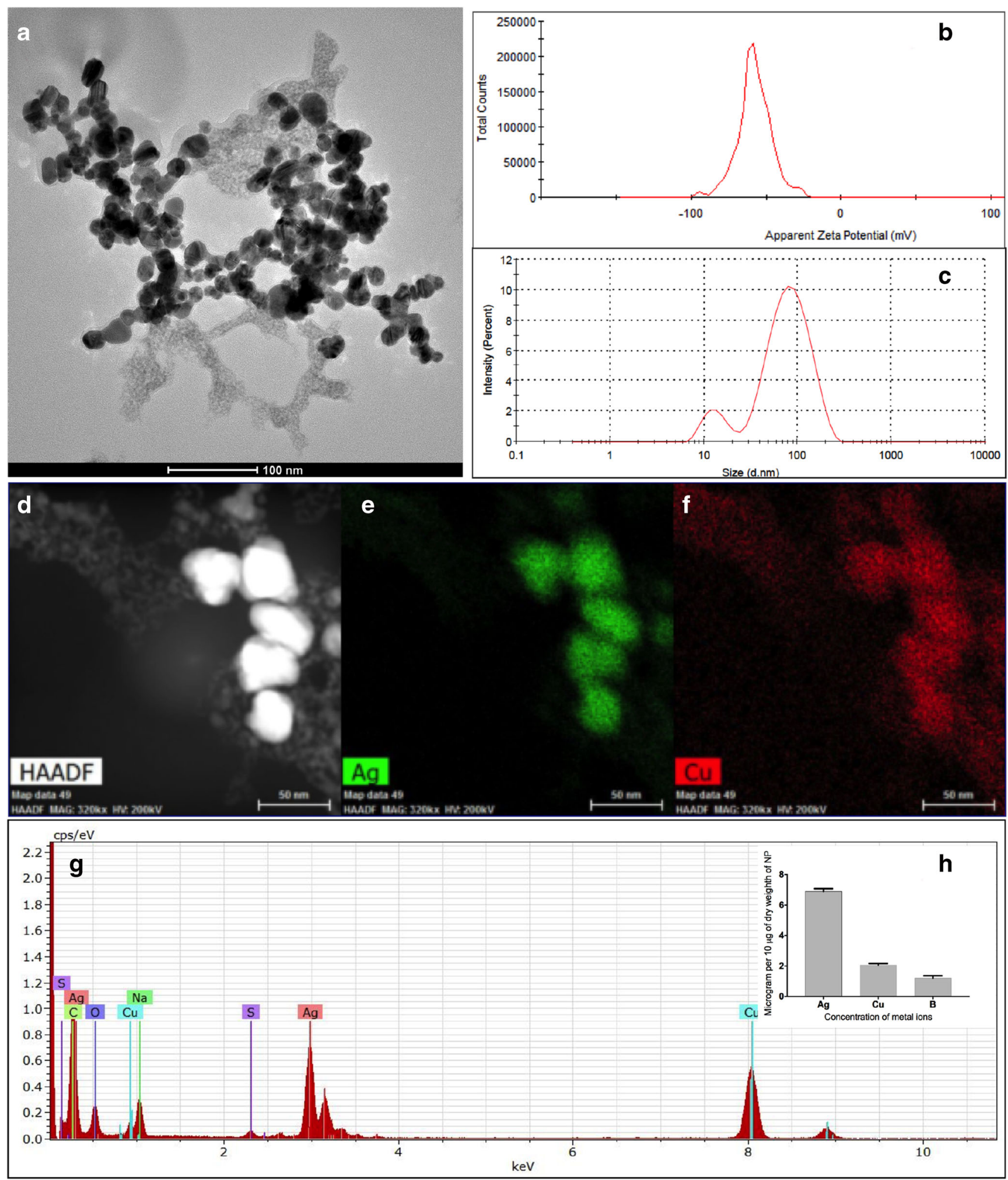

Fig. 1 Nanoparticle characterization. The TEM (TalosF200X) was used to analyze the size and shape (A). The hydrodynamic size and zetapotential (B and C). The Energy Dispersive X-ray (EDX) detector coupled to TEM was used to identify distribution of elements in nanoparticles $(\mathrm{D}-\mathrm{G})$. The ICP-OES measurements for $\mathrm{Ag}, \mathrm{Cu}$, and $\mathrm{B}$ are plotted in bar graph $(\mathrm{I}-\mathrm{H})$

cell) viability and proliferation is not affected by the viability

of internalized $S$. aureus, the toxicity of NPs of varying the longevity of the nanoparticle that resulted in continuous release of ions over time. To ensure the host cell (osteoblast 
Fig. 2 S. aureus growth curves and inhibition of $S$. aureus by nanoparticles. The saturation curves of $S$. aureus, when grown in TSB broth or in DMEM media (A). The inhibitory effect of $\mathrm{AgCuB} \mathrm{NPs}$ on $\mathrm{S}$. aureus grown in DMEM:F12 cell culture media (B). The number of CFU's per milliliter of TSB media corresponding to OD values were plotted (C). In an invasion assay, nanoparticles were incubated with S. aureus-infected osteoblast cells for 24 or $48 \mathrm{~h}$ and the internalized antimicrobial effect (D). Each bar graph represents the mean with \pm STDEV error

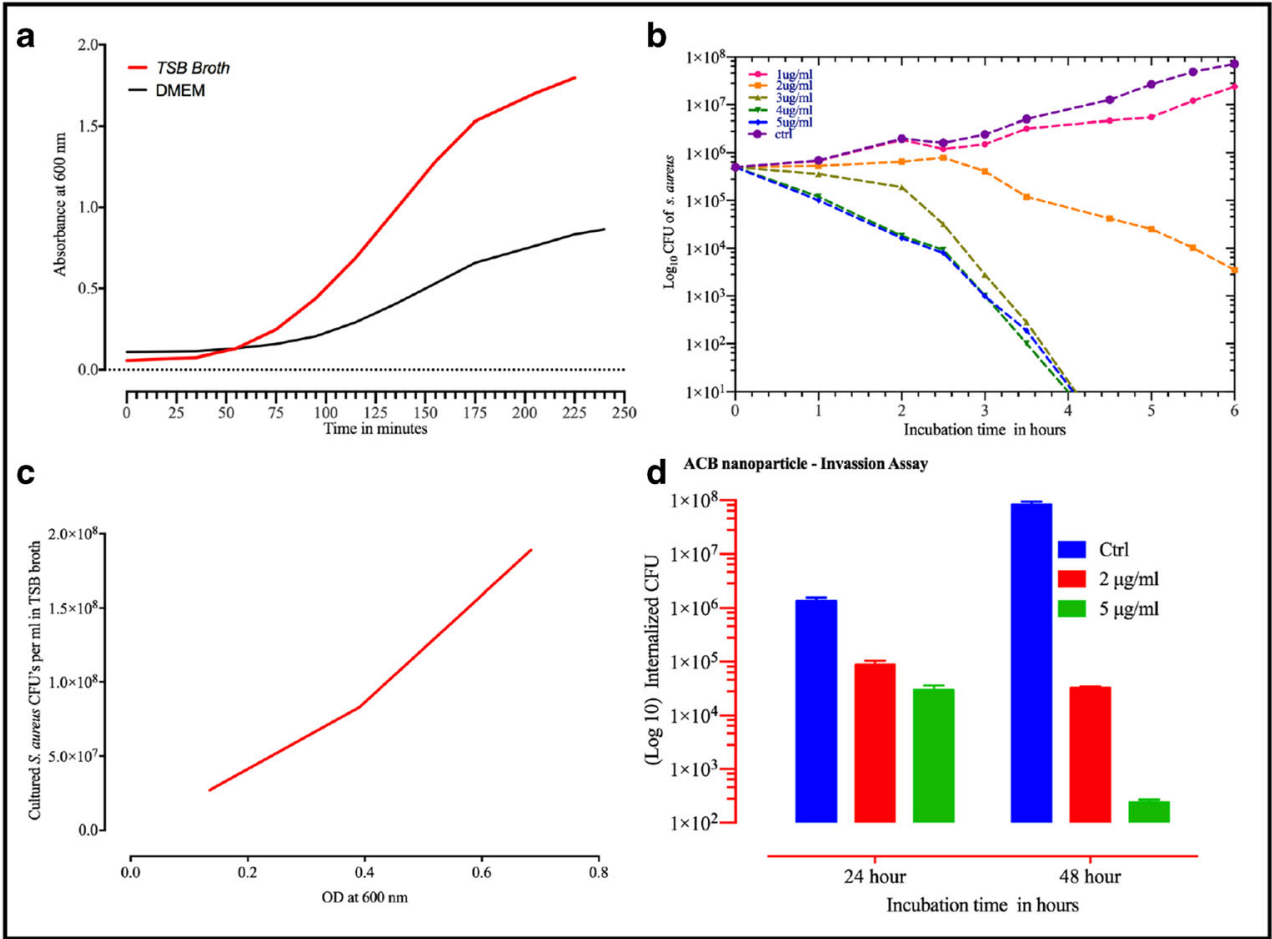

concentrations from 1 to $20 \mu \mathrm{g} / \mathrm{ml}$ was tested for up to $72 \mathrm{~h}$ of incubation times using Wst1 cell survival and proliferation assay. There was no effect on survival of osteoblast cells for concentrations up to $15 \mu \mathrm{g} / \mathrm{ml}$. Osteoblast cells can tolerate up to 5 to 7 days of $S$. aureus infection $[31,32]$. In this study, the length of internalized infection was selected to a maximum of $48 \mathrm{~h}$ in order to maintain $99 \%$ viability of osteoblast cells postinfection. We found that the osteoblast cell viability was $99 \%$ post $48 \mathrm{~h}$ of infection. Hence, the significant reduction of internalized CFUs observed in osteoblast cells is solely due to the antimicrobial effect of $\mathrm{AgCuB}$ NPs.

\subsection{Live and dead bacteria in infected osteoblast cells}

Visual confirmation of the antimicrobial property of the AgCuB nanoparticles in osteoblast cells invaded by S. aureus bacteria is shown in Fig. 3. The SYTO-9 and PI dyes are permeabilized in osteoblast cells; hence, osteoblast nuclei are deeply stained with red. Internalized live $S$. aureus bacterial cells are stained with SYTO-9 only, while dead bacteria are permeable to both SYTO-9 and PI dye. Figure 3A shows healthy osteoblast cells without $S$. aureus infection. Figure $3 \mathrm{~B}$ represents the osteoblast cells invaded with $S$. aureus without antibiotic or nanoparticle treatment. This group showed large accumulation of live $S$. aureus and was clearly visible in the green channel only. Figure 3C shows S. aureus-infected osteoblast cells that were treated with gentamicin which shows the sparse distribution of live bacteria inside the cells compared with non-treated group (Fig. 3B).
Gentamicin has been used to clear the extracellular infection without eradicating internalized bacteria. In this group, it is observed that there is reduced growth of internalized live $S$. aureus compared with the control group. This reduced growth was predicted because there was no extracellular $S$. aureus approaching to enhance the infection. The NPtreated group, as shown in Fig. 3D, the infected $S$. aureus osteoblast cells show more dead bacteria within the host (osteoblast) cells compared with the group treated with gentamicin shown in Fig. 3C. The results support that AgCuB NPs are able to eradicate effectively intracellular $S$. aureus infections in osteoblast cells.

\subsection{Proliferation assay and oxidative stress}

Silver nanoparticle toxicity has been studied in in vitro and in vivo. Silver nanoparticles induce toxicity in osteoblast cells that is dose-dependent [33]. In here, we evaluated the toxicity of $\mathrm{AgCuB}$ NPs on cocultured osteoblasts. Cell viability or proliferation assay or cytotoxic assay is employed to study $\mathrm{AgCuB}$ NP toxicity; all three assays are measuring mitochondrial dehydrogenase enzyme; however, the mechanism of NP caused oxidative stress or damage is still not evident. We measured the cytotoxicity of $\mathrm{AgCuB}$ NPs towards the human osteoblast hFOB 1.19 cell line using the Wst1 assay kit which causes enzymatic cleavage of tetrazolium salt Wst1 to formazan by mitochondrial dehydrogenases enzyme present in viable cells. In osteoblast cells cultured in the presence or absence of $\mathrm{AgCuB}$ nanoparticles with various concentrations 

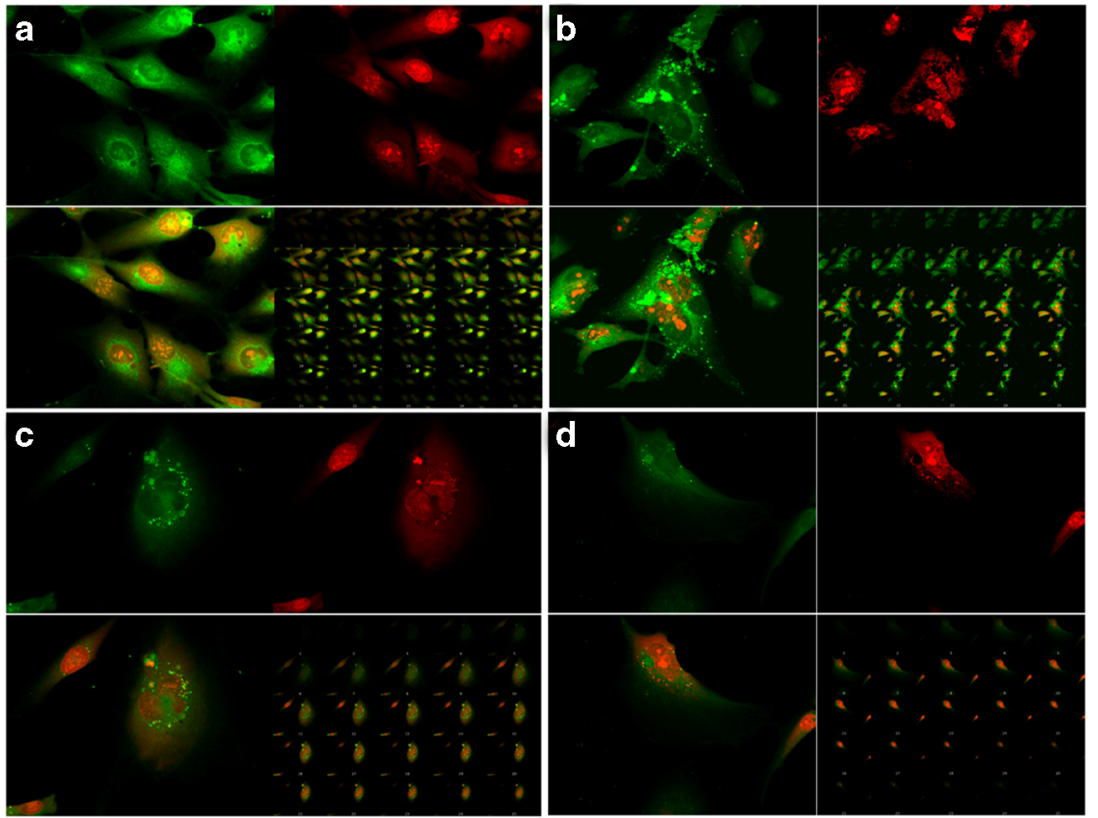

Fig. 3 Confocal microscopy images at $\times 63$ magnification each figure of red, green, or merged has an image resolution of $600 \times 800$ while as montage figure in each panel has image resolution of $1000 \times 750$. Each panel represents both live or dead bacteria; green channel SYTO-9 stained represents both live or dead; red channel propidium iodide stained represents only dead bacteria cells. Lower left image in each panel represents the merged channels of red and green, and each panel with lower right image is montage of hyper stack of red and green channels; each

of NPs as shown in Fig. 4A, we found that $20 \mu \mathrm{g} / \mathrm{ml}$ or higher of $\mathrm{AgCuB}$ NPs showed significant toxicity after $24 \mathrm{~h}$ of NPs' incubation. The toxicity observed corresponded to a 50\% drop in viability compared with its control. Hence, we believe $20 \mu \mathrm{g} / \mathrm{ml}$ or above is an acute toxic dose. The $\mathrm{AgCuB}$ nanoparticles were incubated with osteoblast for $48 \mathrm{~h}$ ranging between 1 and $10 \mu \mathrm{g} / \mathrm{ml}$; there was no drop in the viability of osteoblast cells (data not shown).

Metal ions of $\mathrm{Ag}, \mathrm{Cu}$ have high affinity to react with thiols and inactivate proteins or enzymes, despite that it can produce free radicals which in turn cause an excess of hydrogen peroxide production in an intracellular environment. Excess of hydrogen peroxide can produce hydroxyl radicals that can lead to oxidation of lipids or proteins that may lead to cellular damage. Among all intracellular free radical scavengers, glutathione (GSH) alone comprises $90 \%$ of all intracellular antioxidants. Glutathione detoxifies the free radicals and reactive oxygen compounds. GSH is employed as one of the oxidative stress markers for cells exposed to nanoparticles [34]. To evaluate the oxidative stress mediated by $\mathrm{AgCuB} \mathrm{NPs,} \mathrm{we} \mathrm{mea-}$ sured reduced GSH for cells treated with or without nanoparticles as shown in Fig. 4B.

We did not observe any significant difference among $\mathrm{AgCuB} \mathrm{NP-treated} \mathrm{groups} \mathrm{compared} \mathrm{with} \mathrm{the} \mathrm{control} \mathrm{group}$ of osteoblast cells. Our findings suggest that up to $15 \mu \mathrm{g} / \mathrm{ml}$ of NPs may not be significantly contributing to cellular damage

frame in montage is $500-\mathrm{nm}$ depth. Osteoblast cells were grown without S. aureus infection and NP treatments (A), S. aureus-invaded osteoblast cells without gentamicin and NPs (B), S. aureus -infected osteoblast cells treated with gentamicin (C), and S. aureus-infected osteoblast cells treated with $\mathrm{AgCuB}$ nanoparticles (D). All images were processed in Fiji (ImageJ) software, and the confocal raw file of hyper-stack was processed in Fiji to obtain figures as shown in each panel

that involves glutathione as antioxidant protection. However, it does not mean that free radicals are not produced; rather, free radicals produced are effectively scavenged by reduced GSH. At $15 \mu \mathrm{g} / \mathrm{ml}$ of NPs, we also observed a $20 \%$ increase in GSH level; however, the $p$ value for unpaired Student's $t$ test was non-significant. The upregulation of GSH level could be by the presence of free radicals and by the feedback mechanism. There is a possibility of overproduction of glutathione. Oxidative stress is considered when the free radicals exceed the antioxidant level and will significantly drop the reduced glutathione level. It was observed in WSt1 proliferation test that at $20 \mu \mathrm{g} / \mathrm{ml} \mathrm{NP}$ concentration or above initiates cell death. Thus, reduced GSH was not measured for the NP concentrations that caused a drop in cell viability of osteoblasts.

The upregulation of reduced GSH may be initiated by mild stress, and we believe some of the free radicals may escape from reduced GSH and can cause oxidation of proteins; hence, we measured protein carbonyl content to confirm the oxidation of proteins by free radicals generated by nanoparticles. Oxidation of amine groups in proteins causes production of protein carbonyl content; therefore, measuring protein carbonyl content could be a direct measure of oxidative stress lead by NPs. We found that $15 \mu \mathrm{g} / \mathrm{ml}$ concentration of $\mathrm{AgCuB}$ NPs caused a significant rise in carbonyl content as shown in Fig. 4C. Thus, a concentration of $15 \mu \mathrm{g} / \mathrm{ml}$ is considered a toxic dose; however, at this concentration, we did not observe any 


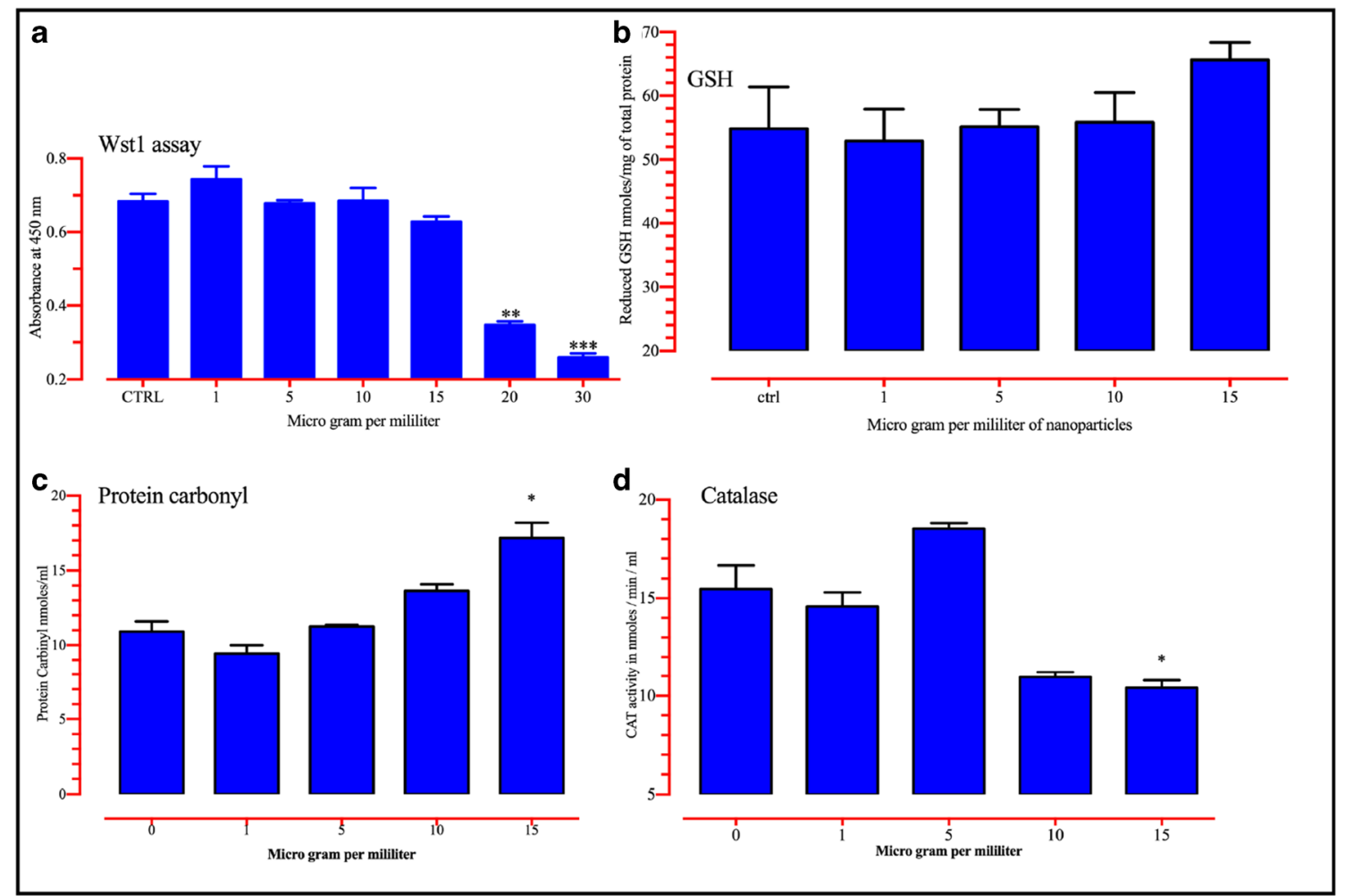

Fig. $4 \mathrm{AgCuB} \mathrm{NP}$ toxicity in osteoblast cells: With or without a varied concentration of $\mathrm{AgCuB} \mathrm{NPs}$, following experiments were performed to measure toxicity (A) proliferation assay by Wst1, (B) reduced glutathione $\mathrm{GSH}$, (C) protein carbonyl content, and (D) catalase activity. Each

drop in reduced glutathione levels. The sensitivity of proteins to free radicals at a point when reduced glutathione level is not dropped may depict that even lower levels of free radicals generated within the cells can escape from the antioxidant system. This data shows that toxicity may be due to direct oxidation of proteins by metal ions or indirectly by generating peroxides. We further measured catalase enzyme activity as shown in Fig. 4D which showed that 10 and $15 \mu \mathrm{g} / \mathrm{ml}$ concentrations pulled down the catalytic activity; however, statistically only $15 \mu \mathrm{g} / \mathrm{ml}$ was significant when compared with control group. Catalase enzyme detoxifies hydrogen peroxide into water and oxygen. $\mathrm{H}_{2} \mathrm{O}_{2}$ is a very unstable molecule. $\mathrm{H}_{2} \mathrm{O}_{2}$ is considered as a secondary intracellular messenger molecule when produced under sub-toxic levels. It is also produced in cells with respect to immune response. If catalase enzyme can detoxify all hydrogen peroxide generated in response to nanoparticle exposure, then there will no cellular damage. Hence, we believe that higher protein carbonyl content at $15 \mu \mathrm{g} / \mathrm{ml}$ of nanoparticles exposure may be generated by access of hydrogen peroxide while at $10 \mu \mathrm{g} / \mathrm{ml}$ concentration of NPs, the catalytic activity is enough to prevent the formation of protein carbonyl content, so we conclude from this experiment that $10 \mu \mathrm{g} / \mathrm{ml}$ concentration could be the borderline for toxicity. experiment was done in triplicate; each bar represents the mean value \pm S.E.M., $p$ values of unpaired $t$ test which are $\leq 0.5, \leq 0.01$, and $\leq$ 0.001 when compared with control correspond to single, double, and triple asterisks, respectively

Hydrogen peroxide generated will react with free metal ions and may form hydroxyl radicals which are deadly toxic radicals that can lead to oxidation of proteins and lipids. It has been reported earlier hydrogen peroxide stress is due to copper oxide by Lobo et al. [35]. We do not argue that NPs cannot cause cellular damage; however, we emphasize that toxicity lead by NPs is dose-dependent and at a certain minimum concentration of nanoparticles may have no toxicity to host cells.

Among reactive oxygen species (ROS), superoxide radical plays a major role in oxidative stress, either directly or indirectly. Superoxide can also cause oxidation of proteins or by the production of hydrogen peroxide. Metal nanoparticles are prone to produce free radicals in aqueous medium or when in contact with free radicals. The copper oxide nanoparticles induce the formation of superoxide and $\mathrm{OH}$ radicals [36]. Superoxide is naturally detoxified by enzyme SOD. To assess the role of superoxide in oxidative stress, we measured SOD activity of the cellular extract of osteoblast cells treated or nontreated with NPs which were earlier tested for carbonyl content. Besides hydroxyl radicals, there is a possibility of generating superoxide from hydrogen peroxide which is detoxified by superoxide dismutase enzyme system. It was not clear which pathway may cause elevated carbonyl content; hence, we measured superoxide dismutase enzyme (SOD) activity as 


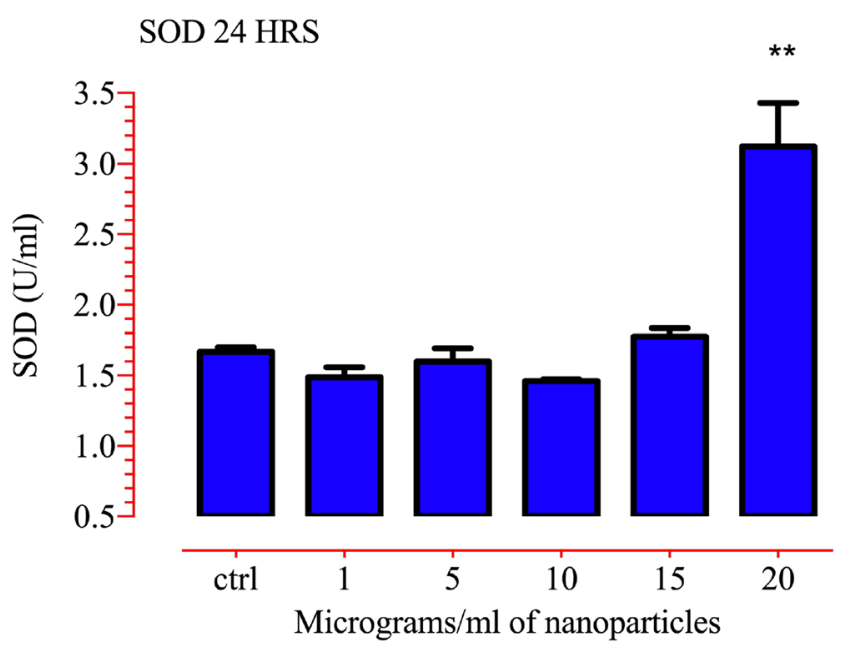

Fig. 5 Superoxide dismutase activity (SOD): Osteoblast cell extract was measured for SOD activity. Each bar represents mean \pm S.E.M, and ** $p \leq$ 0.01 of unpaired $t$ test

shown in Fig. 5 and we did not observe any significant change in SOD enzyme levels among groups treated with NPs up to
$15 \mu \mathrm{g} / \mathrm{ml}$ for 24-h incubation time compared with the control group. However, at $20 \mu \mathrm{g} / \mathrm{ml}$, there was a significant rise in SOD enzyme activity but it was evident from the Wst1 proliferation assay that more than $50 \%$ of cells were dead at $20 \mu \mathrm{g} / \mathrm{ml}$; hence, at this concentration, superoxide could have played a role in cellular toxicity. The test was repeated for the $48 \mathrm{~h}$ of incubation and there was no significant change in SOD levels observed for the treated vs. non-treated (data not shown). We depicted from the data that the oxidation of proteins at $15 \mu \mathrm{g} / \mathrm{ml}$, as shown above, may not necessarily be via superoxide production.

To summarize, a possible mechanism of AgCuB NP could be attributed to the interaction of metal ions with the intercellular free hydrogen peroxide which is generated by superoxide dismutase in presence of superoxide; superoxide is considered as secondary messenger molecule which is produced from mitochondrial cytochrome P450 enzyme system and NADPH oxidase. Overproduction of superoxide has been shown related to immune response or in phagocytic action. The toxicity by metal ions could be by the production of
Fig. 6 Sketch of possible mechanisms of $\mathrm{AgCuB} \mathrm{NP}$ interaction with free hydrogen peroxide. The nanoparticles or its released ions can directly enter the cells which lead to toxicity. The generation or overproduction of hydroxyl radicals is more toxic to cells because there is not any antioxidant known that can neutralize hydroxyl radicals. The increased production of radicals is generated from secondary messenger molecules such as hydrogen peroxide from the precursor superoxide by superoxide dismutase. Hydrogen peroxide generated is converted to water molecule and oxygen by a catalase enzyme; however, if the metal ions or metal nanoparticles are exposed to hydrogen peroxide, there is an equal chance of interaction of metal ions and catalase enzyme. Metal ions react with hydrogen peroxide and generate $\mathrm{OH}$ radical which oxidize lipids, proteins, DNA, and RNA leading to cell death

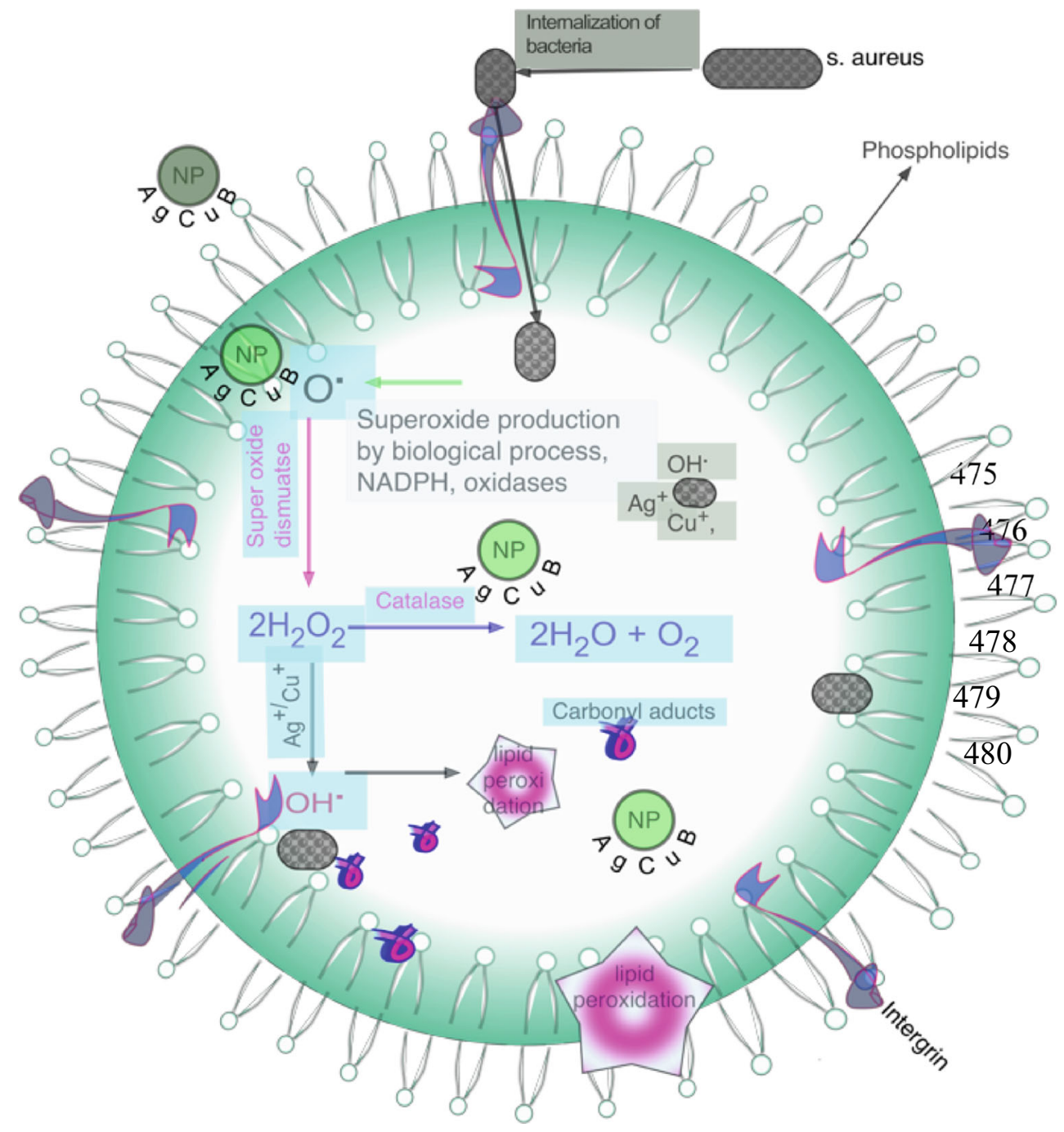


hydroxyl radicals that interacts with cellular hydrogen peroxide. There is no known radical scavenger that will act on hydroxyl radicals, and as a result, it can rapidly cause oxidation of proteins or lipids that leads to cellular damage. Figure 6 shows a schematic sketch of the possible mechanism.

In addition to antioxidant levels, we examined the membrane integrity by measuring the lactate dehydrogenase enzyme (LDH) release from the treated and non-treated osteoblast cells which accounts for membrane damage. We found that nanoparticle concentration ranging from 1 to $10 \mu \mathrm{g} / \mathrm{ml}$ did not show any significant change compared with control; however, at $15 \mu \mathrm{g} / \mathrm{ml}$, the viability dropped by $5 \%$ as shown in Fig. 7. The $t$ test was non-significant with $p$ value $>0.5$ while at $20 \mu \mathrm{g} / \mathrm{ml}$, the viability dropped by $13 \%$ with unpaired $t$ test and $p$ value 0.0018 . Our results testify that $20 \mu \mathrm{g} / \mathrm{ml}$ which was toxic dose has significant membrane damage that causes cell death while at $15 \mu \mathrm{g} / \mathrm{ml}$, the cells are susceptible to
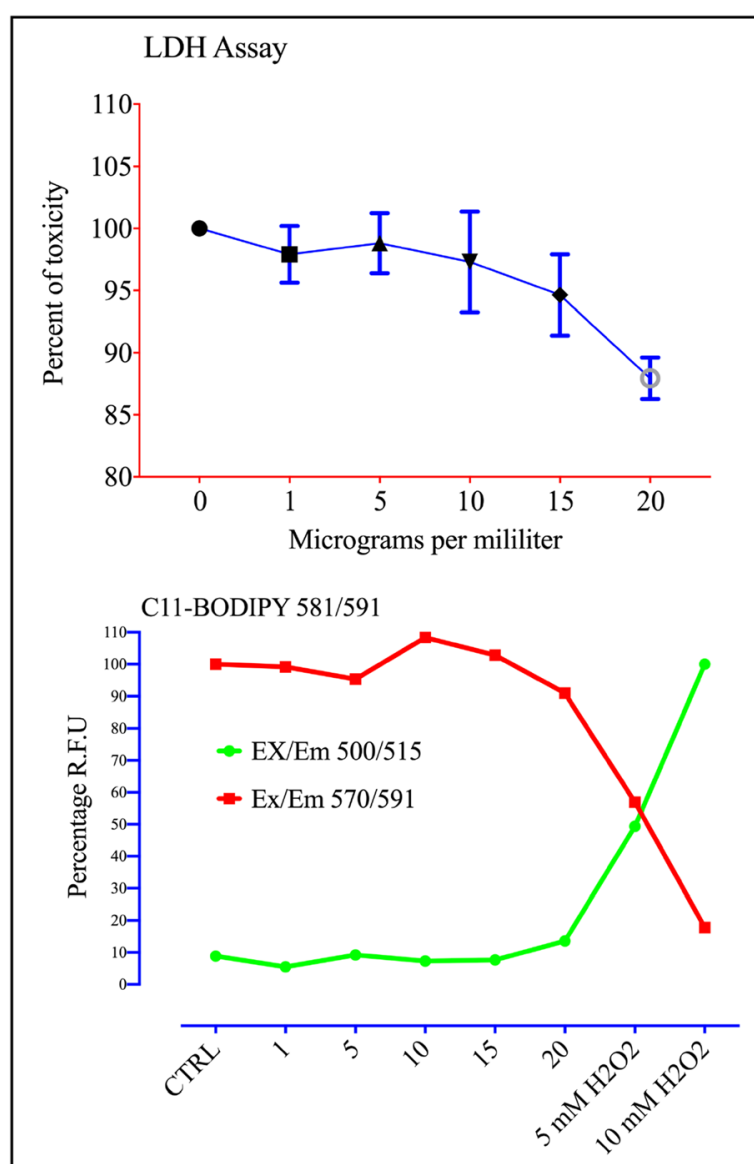

Fig. 7 LDH assay and C11 BODIPY: (A) LDH (lactate dehydrogenase) experiment and (B) C11-BODYIP assay. Each experiment was done in triplicate and values in $\mathrm{XY}$ scatter line plot showed the mean value \pm S.E.M., In LDH assay, the non-treated group of osteoblast cells were considered as $100 \%$ viability and treated samples were normalized with control group. Ratio fluorescence spectroscopic detection of lipid peroxidation by C11-BODIPY 581/591 fluorophores is shown in the lower panel membrane damage, which confirms our previous observations where protein carbonyl and catalase activity at $15 \mu \mathrm{g} / \mathrm{ml}$ were significantly toxic compared with control group. Altogether, our data summarizes that exposure up to $15 \mu \mathrm{g} / \mathrm{ml}$ concertation where oxidative stress may be generated does not affect the viability of osteoblast cells. Our results clearly indicated that $10 \mu \mathrm{g} / \mathrm{ml}$ concentration of $\mathrm{AgCuB}$ nanoparticles did not exhibit any toxicity.

LDH was measured from the growth media of growing osteoblast cells after $24 \mathrm{~h}$ of incubation with or without a varied concentration of NPs as shown in Fig. 7A. Our results showed that LDH concentration did not vary considerably up to $10 \mu \mathrm{g} / \mathrm{ml}$ of NPs, while at 15 or $20 \mu \mathrm{g} / \mathrm{ml}$, it showed increased toxicity by $5 \%$ or $15 \%$, respectively. This data also showed resemblance with the Wst1 toxicity assay where $20 \mu \mathrm{g} / \mathrm{ml}$ was significantly toxic dose. LDH release from the cells is due to loss in the integrity of cell membrane either by lipid peroxidation of membrane or membrane protein damage. In order to see the effect of nanoparticles on lipid peroxidation, we used C11-BODIPY fluorophores for monitoring lipid oxidation by undecylamine fluorescein and hexadecanoyl BODYIP-FL, which monitors the only non-oxidized form of these fluorophores; however, BODYIP 581/591 is very suitable for ratio-fluorescence of the oxidation process in membranes of living cells [37]. It was reported that C11-BODIPY is susceptible to oxidation and thereby losing its bright red fluorescence and shifting towards shorter wavelength of excitation and emission 500/510, both spectra are well separated and are used to quantify the fraction of oxidized and non-oxidized C11-BODIPY 581/591 simultaneously. These fluorophores are called surrogate markers of lipid peroxidation [37]. We did not observe any shift from red to green wavelength emission for concentration ranging between 1 and $15 \mu \mathrm{g} / \mathrm{ml}$; however, for $20 \mu \mathrm{g} / \mathrm{ml}$, we observed $13 \%$ signal loss in red and $10 \%$ gain in green. Positive controls treated with $5 \mathrm{mM}$ or $10 \mathrm{mM}$ of hydrogen peroxide exhibited the shift in wavelength by $50 \%$ or more as shown in Fig. 7. Our data showed that $20 \mu \mathrm{g} / \mathrm{ml}$ concentration of NPs caused membrane damage by lipid peroxidation in $24 \mathrm{~h}$ of incubation time. The mild oxidative stress may not be acute to cause toxicity; however, prolonged exposure could be harmful, so a stress-free nanoparticle concentration is definitely required which possess effective antimicrobial function for long-term therapy as an alternative to antibiotics. Our results demonstrate that $2 \mu \mathrm{g} / \mathrm{ml}$ concentration of NPs showed 99\% killing of intracellular bacterial infection which is 10-fold away from the toxic dose.

\section{Conclusion}

$\mathrm{AgCuB}$ were synthesized with an average size of $20 \mathrm{~nm}$. $\mathrm{AgCuB}$ NPs have a great potential to eradicate $S$. aureus invaded into osteoblast cells without harming the osteoblasts if 
the NPs are administered below $15 \mu \mathrm{g} / \mathrm{ml}$. An effective dose to eradicate intercellular bacterial infection was found to be at $2 \mu \mathrm{g} / \mathrm{ml}$ leading to $99 \%$ eradication of intercellular bacteria. The results show that the possible mechanism of the $\mathrm{AgCuB}$ antimicrobial activity could be attributed to hydroxyl radicals generated by metal ions reacting with intracellular hydrogen peroxide leading to cellular damage.

Data availability statement All data presented in this article are available with the corresponding author.

Authors' contributions Yousef Haik is the lead PI of the grant, designed the study, analyzed the data, and edited the manuscript.

Shahnaz Qadri is a postdoctoral fellow, collected the data, assembled the figures, and drafted the manuscript

Jamil Azzi participated in toxicity experiments, collection and analysis, and edited the manuscript.

Said Mansour conducted the particles electron microscopy characterization.

Funding information Open Access funding provided by the Qatar National Library. This work has been supported by the grant from Qatar National Research Fund. Grant number NPRP8-1744-3-357X

\section{Compliance with ethical standards}

Conflict of interest The authors declare that they have no conflict of interest.

Open Access This article is distributed under the terms of the Creative Commons Attribution 4.0 International License (http:// creativecommons.org/licenses/by/4.0/), which permits unrestricted use, distribution, and reproduction in any medium, provided you give appropriate credit to the original author(s) and the source, provide a link to the Creative Commons license, and indicate if changes were made.

\section{References}

1. F.A. Waldvogel, H. Vasey, Osteomyelitis: The past decade. N. Engl. J. Med. 303, 360-370 (1980)

2. D.P. Lew, F.A. Waldvogel, Osteomyelitis. Lancet 364, 369-379 (2004)

3. M. Deysine, Infections associated with surgical implants. N. Engl. J. Med. 351, 193-195; author reply 193-195 (2004)

4. T.J. Foster, J.A. Geoghegan, V.K. Ganesh, M. Hook, Adhesion, invasion and evasion: the many functions of the surface proteins of Staphylococcus aureus. Nat. Rev. Microbiol. 12, 49-62 (2014)

5. M.J. Bosse, H.E. Gruber, W.K. Ramp, Internalization of bacteria by osteoblasts in a patient with recurrent, long-term osteomyelitis. A case report. J. Bone Joint Surg. Am. 87, 1343-1347 (2005)

6. H. Boucher, L.G. Miller, R.R. Razonable, Serious infections caused by methicillin-resistant Staphylococcus aureus. Clin. Infect. Dis. 51, S183-S197 (2010)

7. V. Thammavongsa, H.K. Kim, D. Missiakas, O. Schneewind, Staphylococcal manipulation of host immune responses. Nat. Rev. Microbiol. 13, 529-543 (2015)

8. E. Campoy, M.I. Colombo, Autophagy in intracellular bacterial infection. Biochimica et Biophysica Acta (BBA) - Molecular Cell Research 1793, 1465-1477 (2009)
9. S.M. Lehar et al., Novel antibody-antibiotic conjugate eliminates intracellular S. aureus. Nature 527, 323-328 (2015)

10. B.R. Levin, D.E. Rozen, Non-inherited antibiotic resistance. Nat. Rev. Microbiol. 4, 556-562 (2006)

11. N. Abed, P. Couvreur, Nanocarriers for antibiotics: a promising solution to treat intracellular bacterial infections. Int. J. Antimicrob. Agents 43, 485-496 (2014)

12. A.M. Rediske, B.L. Roeder, M.K. Brown, J.L. Nelson, R.L. Robison, D.O. Draper, G.B. Schaalje, R.A. Robison, W.G. Pitt, Ultrasonic enhancement of antibiotic action on Escherichia coli biofilms: an in vivo model. Antimicrob. Agents Chemother. 43, 1211-1214 (1999)

13. M.J. Hajipour et al., Antibacterial properties of nanoparticles. Trends Biotechnol. 30, 499-511

14. J.A. Lemire, J.J. Harrison, R.J. Turner, Antimicrobial activity of metals: mechanisms, molecular targets and applications. Nat. Rev. Microbiol. 11, 371-384 (2013)

15. J.J. Harrison, R.J. Turner, D.A. Joo, M.A. Stan, C.S. Chan, N.D. Allan, H.A. Vrionis, M.E. Olson, H. Ceri, Copper and quaternary ammonium cations exert synergistic bactericidal and antibiofilm activity against Pseudomonas aeruginosa. Antimicrob. Agents Chemother. 52, 2870-2881 (2008)

16. A. Perdikaki, A. Galeou, G. Pilatos, I. Karatasios, N.K. Kanellopoulos, A. Prombona, G.N. Karanikolos, Ag and $\mathrm{Cu}$ monometallic and ag/cu bimetallic nanoparticle-graphene composites with enhanced antibacterial performance. ACS Appl. Mater. Interfaces 8, 27498-27510 (2016)

17. J.R. Morones-Ramirez, J.A. Winkler, C.S. Spina, J.J. Collins, Silver enhances antibiotic activity against gram-negative bacteria. Sci. Transl. Med. 5, 190ra181 (2013)

18. M. Taner, N. Sayar, I.G. Yulug, S. Suzer, Synthesis, characterization and antibacterial investigation of silver-copper nanoalloys. J. Mater. Chem. 21, 13150-13154 (2011)

19. S. Qadri, Y. Haik, E. Mensah-Brown, G. Bashir, M.J. FernandezCabezudo, B.K. al-Ramadi, Metallic nanoparticles to eradicate bacterial bone infection. Nanomedicine 13, 2241-2250 (2017)

20. K. B. Ramadi et al., Acute systemic exposure to silver-based nanoparticles induces hepatotoxicity and NLRP3-dependent inflammation. Nanotoxicology, 1-46 (2016)

21. D. Prasai, J.C. Tuberquia, R.R. Harl, G.K. Jennings, B.R. Rogers, K.I. Bolotin, Graphene: corrosion-inhibiting coating. ACS Nano 6 , 1102-1108 (2012)

22. F. Mahvash, S. Eissa, T. Bordjiba, A.C. Tavares, T. Szkopek, M. Siaj, Corrosion resistance of monolayer hexagonal boron nitride on copper. Sci. Rep. 7, 42139 (2017)

23. Y. Wang, B. Ren, X. Zhou, S. Liu, Y. Zhou, B. Li, Y. Jiang, M. Li, M. Feng, L. Cheng, Growth and adherence of Staphylococcus aureus were enhanced through the PGE2 produced by the activated COX-2/PGE2 pathway of infected oral epithelial cells. PLoS One 12, e0177166 (2017)

24. A. Zorzoli, J.P. Grayczyk, F. Alonzo III, Staphylococcus aureus tissue infection during sepsis is supported by differential use of bacterial or host-derived lipoic acid. PLoS Pathog. 12, e1005933 (2016)

25. M. Balouiri, M. Sadiki, S.K. Ibnsouda, Methods for in vitro evaluating antimicrobial activity: a review. J Pharm Anal 6, 71-79 (2016)

26. R.D. Ning, X.L. Zhang, Q.T. Li, X.K. Guo, The effect of Staphylococcus aureus on apoptosis of cultured human osteoblasts. Orthop. Surg. 3, 199-204 (2011)

27. C.A. Coleman, B.E. Hull, J.N. McDougal, J.V. Rogers, The effect of m-xylene on cytotoxicity and cellular antioxidant status in rat dermal equivalents. Toxicol. Lett. 142, 133-142 (2003)

28. J.P. Ruparelia, A.K. Chatterjee, S.P. Duttagupta, S. Mukherji, Strain specificity in antimicrobial activity of silver and copper nanoparticles. Acta Biomater. 4, 707-716 (2008) 
29. H. Pang, F. Gao, Q. Lu, Morphology effect on antibacterial activity of cuprous oxide. Chem Commun, 1076-1078 (2009)

30. M. Hans, A. Erbe, S. Mathews, Y. Chen, M. Solioz, F. Mücklich, Role of copper oxides in contact killing of bacteria. Langmuir $\mathbf{2 9}$, 16160-16166 (2013)

31. T. Hamza, B. Li, Differential responses of osteoblasts and macrophages upon Staphylococcus aureus infection. BMC Microbiol. 14, 207 (2014)

32. T. Hamza et al., Intra-cellular Staphylococcus aureus alone causes infection in vivo. Eur. Cell. Mater. 25, 341-350; discussion 350 (2013)

33. C.E. Albers, W. Hofstetter, K.A. Siebenrock, R. Landmann, F.M. Klenke, In vitro cytotoxicity of silver nanoparticles on osteoblasts and osteoclasts at antibacterial concentrations. Nanotoxicology 7 , 30-36 (2013)

34. A. Dubey, M. Goswami, K. Yadav, D. Chaudhary, Oxidative stress and nano-toxicity induced by $\mathrm{TiO} 2$ and $\mathrm{ZnO}$ on WAG cell line. PLoS One 10, e0127493 (2015)

35. V. Lobo, A. Patil, A. Phatak, N. Chandra, Free radicals, antioxidants and functional foods: impact on human health. Pharmacogn. Rev. 4 118-126 (2010)

36. P.P. Fu, Q. Xia, H.-M. Hwang, P.C. Ray, H. Yu, Mechanisms of nanotoxicity: generation of reactive oxygen species. J. Food Drug Anal. 22, 64-75 (2014)

37. E.H. Pap et al., Ratio-fluorescence microscopy of lipid oxidation in living cells using C11-BODIPY(581/591). FEBS Lett. 453, 278282 (1999) 